Article

\title{
The First Report of Polymorphisms and Genetic Features of the prion-like Protein Gene (PRND) in a Prion Disease-Resistant Animal, Dog
}

\author{
Sae-Young Won ${ }^{1,2,+}$, Yong-Chan Kim ${ }^{1,2,+}$, Kiwon Kim ${ }^{3}$, An-Dang Kim ${ }^{4}$ and \\ Byung-Hoon Jeong 1,2,*(D) \\ 1 Korea Zoonosis Research Institute, Chonbuk National University, Iksan, Jeonbuk 54531, Korea; \\ gkfh32@jbnu.ac.kr (S.-Y.W.); kych@jbnu.ac.kr (Y.-C.K.) \\ 2 Department of Bioactive Material Sciences, Chonbuk National University, Jeonju, Jeonbuk 54896, Korea \\ 3 Haemalken Animal Hospital, Yangju, Gyeonggi 11492, Korea; kkw0075@hanmail.net \\ 4 Cool-Pet Animal Hospital, Anyang, Gyeonggi 14066, Korea; kad7582@hanmail.net \\ * Correspondence: bhjeong@jbnu.ac.kr; Tel.: +82-63-900-4040; Fax: +82-63-900-4012 \\ + These authors contributed equally to this work.
}

Received: 22 February 2019; Accepted: 18 March 2019; Published: 20 March 2019

\begin{abstract}
Prion disease has displayed large infection host ranges among several species; however, dogs have not been reported to be infected and are considered prion disease-resistant animals. Case-controlled studies in several species, including humans and cattle, indicated a potent association of prion protein gene (PRNP) polymorphisms in the progression of prion disease. Thus, because of the proximal location and similar structure of the PRNP gene among the prion gene family, the prion-like protein gene $(P R N D)$ was noted as a novel candidate gene that contributes to prion disease susceptibility. Several case-controlled studies have confirmed the relationship of the PRND gene with prion disease vulnerability, and strong genetic linkage disequilibrium blocks were identified in prion-susceptible species between the PRNP and PRND genes. However, to date, polymorphisms of the dog PRND gene have not been reported, and the genetic linkage between the PRNP and $P R N D$ genes has not been examined thus far. Here, we first investigated $\operatorname{dog} P R N D$ polymorphisms in 207 dog DNA samples using direct DNA sequencing. A total of four novel single nucleotide polymorphisms (SNPs), including one nonsynonymous SNP (c.149G>A, R50H), were identified in this study. We also found two major haplotypes among the four novel SNPs. In addition, we compared the genotype and allele frequencies of the c.149G $>$ A (R50H) SNP and found significantly different distributions among eight dog breeds. Furthermore, we annotated the c.149G $>$ A (R50H) SNP of the dog PRND gene using in silico tools, PolyPhen-2, PROVEAN, and PANTHER. Finally, we examined linkage disequilibrium between the PRNP and PRND genes in dogs. Interestingly, we did not find a strong genetic linkage between these two genes. To the best of our knowledge, this was the first genetic study of the PRND gene in a prion disease-resistant animal, a dog.
\end{abstract}

Keywords: dog; prion-like protein gene; PRND; Doppel; linkage disequilibrium; prion

\section{Introduction}

Prion diseases, neurodegenerative disorders in humans and animals, are also known as transmissible spongiform encephalopathies (TSEs) characterized by a structural folding change from a normal prion protein $\left(\mathrm{PrP}^{\mathrm{C}}\right)$ to a toxic form of prion protein $\left(\mathrm{PrP}^{\mathrm{Sc}}\right)$ causing brain lesions [1-3]. The most represented TSEs are scrapie in sheep and goats; chronic wasting disease (CWD) in elk and deer [4-7]; bovine spongiform encephalopathy (BSE) in cattle [8,9]; transmissible mink encephalopathy (TME) in minks [10]; feline spongiform encephalopathy (FSE) in cheetahs, pumas and cats [11-13]; 
and Creutzfeldt-Jakob disease (CJD), fatal familial insomnia (FFI) and Gerstmann-Sträussler Scheinker syndrome (GSS) in humans [14,15]. Interestingly, although dogs and cats have similar prey and habitats, prion disease in dogs has not been reported thus far. Therefore, many studies have been performed in dogs to identify factors that affect the resistance to prion disease.

According to previous studies, susceptibility to prion disease can be influenced by three major factors. One is the amount of prion protein expression. The 12-bp and 23-bp insertion/deletion (indel) polymorphisms in the promoter region of the bovine PRNP gene have been strongly associated with the expression level of bovine prion protein and the susceptibility to prion disease in cattle. Overexpression of prion protein based on the haplotype of 23-bp and 12-bp polymorphisms has been considered a vulnerability factor for BSE $[8,16,17]$. In addition, ablation of prion protein in knockout animals did not cause infection with prion disease [18]. However, there was no significant difference in the expression level of prion protein in the brain between dogs and other animals [19]. Another factor is the genetic characteristic of the prion protein. Polymorphisms of the prion protein gene (PRNP) in several species have been shown to be strongly correlated with prion disease susceptibility. In sheep, the haplotypes of codons 136, 154 and 171 affect susceptibility (VRQ, ARQ) or resistance (ARR) to scrapie $[20,21]$. The goat prion protein codon M142 extends the scrapie incubation period. In addition, codons S146N, R154H and Q222K protect against scrapie [22-26]. In humans, the PRNP genotypes of codons 129 and 219 are well known for being factors of CJD susceptibility $[27,28]$. In prion-resistant species, the dog prion protein D163 residue strongly contributes to prion disease resistance [29-35]. However, because a high dose of $\mathrm{PrP}^{\mathrm{Sc}}$ infection converted $\operatorname{dog} \mathrm{PrP}^{\mathrm{C}}$ to $\mathrm{PrP}^{\mathrm{Sc}}$, it is not sufficient to fully explain prion disease resistance in dogs [19]. The other factor is other candidate genes besides prion protein that can affect the susceptibility to prion diseases. Among them, the prion-like protein gene $(P R N D)$ is a potent candidate gene that may play a role in prion disease susceptibility. According to case-controlled studies comparing the genetic distribution of $P R N D$ gene polymorphisms in codons $26,56,132$ and 174 and $3^{\prime}$ untranslated region (UTR) +28 , these polymorphisms were involved in the susceptibility to scrapie, BSE and sporadic CJD in ruminants and humans [36-40]. In addition, recent studies have reported a strong linkage disequilibrium (LD) between the PRNP gene and PRND gene in prion disease-susceptible species, sheep and goats [38,41]. However, no study has been conducted on the genetic characteristics of $P R N D$ in dogs. Thus, the investigation of the genetic characteristics of the $P R N D$ gene in dogs as a prion disease-resistant species will be a very important baseline study to obtain clues on the progression of prion disease.

In the present study, we investigated the dog PRND genotype, allele and haplotype frequencies of single nucleotide polymorphisms (SNPs). We also annotated nonsynonymous SNPs using in silico analysis tools, PolyPhen-2 [42], PROVEAN [43,44] and PANTHER [45]. In addition, we performed LD tests among PRND SNPs and analyzed major haplotypes of PRND SNPs. Furthermore, we measured the LD value between the PRNP gene and PRND gene in dogs.

\section{Results}

\subsection{Investigation of Genetic Characteristics of the PRND Gene in the 207Dogs}

The dog PRND gene is composed of two exons. To investigate polymorphisms of the PRND gene in dogs, we performed direct sequencing analysis targeting exon 2 , which contains the full length ORF. We found a total of four novel SNPs: c.149G >A, c.447T >C, c.465C $>$ T in the ORF and c.556G $>C$ in the $3^{\prime}$ UTR of the PRND gene (Figure 1a,b). 

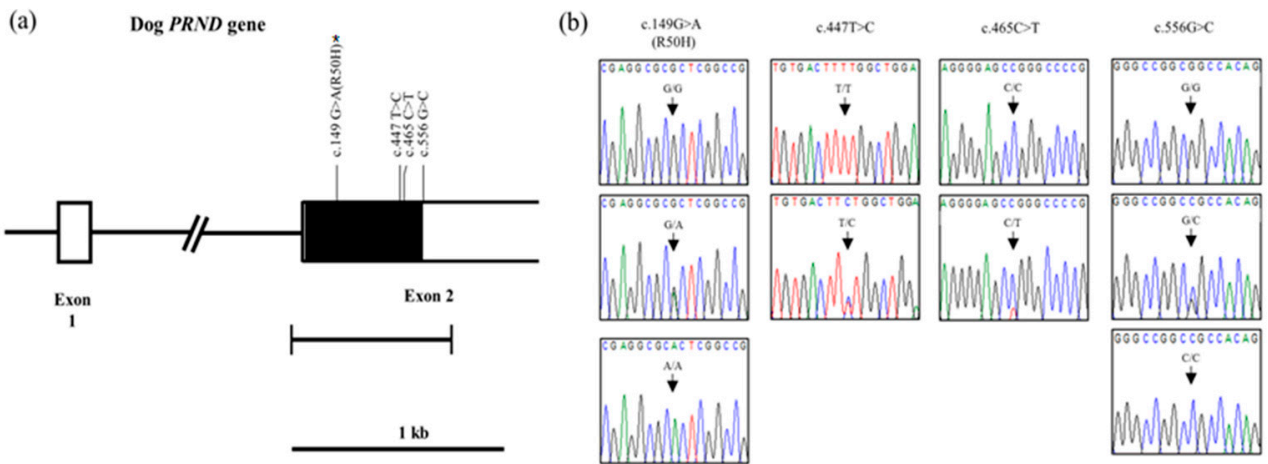

Figure 1. Gene map and polymorphisms identified in the dog prion-like protein gene (PRND) on chromosome 24. (a) The open reading frame (ORF) is indicated by a shaded block, and the $5^{\prime}$ and $3^{\prime}$ untranslated regions (UTRs) are indicated by white blocks. Horizontal bars with edges indicate the regions sequenced. Arrows indicate the novel polymorphisms found in this study. The asterisk indicates the nonsynonymous single nucleotide polymorphism (SNP) of the dog PRND gene. (b) Electropherogram of four novel SNPs: c.149G>A (R50H), c.447T>C (F149F), c.465C > T (A155A) and c.556G $>C$, identified in this study. Four colors indicate individual bases of DNA sequence using an ABI 3730 automatic sequencer (blue: cytosine, red: thymine, black: guanine, green: adenine).

Among the four SNPs, c.149G>A (R50H) is a nonsynonymous SNP. Detailed values of the genotype and allele frequencies of the dog PRND gene are described in Table 1.

Table 1. Genotype and allele frequencies of $P R N D$ polymorphisms in dogs.

\begin{tabular}{cccccc}
\hline Polymorphisms & \multicolumn{3}{c}{ Genotype Frequency, $\boldsymbol{n}$ (\%) } & \multicolumn{2}{c}{ Allele Frequency, $\boldsymbol{n} \mathbf{( \% )}$} \\
\hline c.149G $>$ A & GG & GA & AA & G & A \\
(R50H) & $164(79.2)$ & $35(16.9)$ & $8(3.9)$ & $363(87.7)$ & $51(12.3)$ \\
c.447T $>$ C & TT & TC & CC & T & C \\
(F149F) & $206(99.5)$ & $1(0.5)$ & $0(0)$ & $413(99.8)$ & $1(0.2)$ \\
c.465C $>$ T & CC & CT & TT & C & T \\
(A155A) & $206(99.5)$ & $1(0.5)$ & $0(0)$ & $413(99.8)$ & $1(0.2)$ \\
c.556G $>$ C & GG & GC & CC & G & C \\
& $164(79.2)$ & $35(16.9)$ & $8(3.9)$ & $363(87.7)$ & $51(12.3)$ \\
\hline
\end{tabular}

We also investigated LD among the four dog PRND SNPs using $\left(\left|\mathrm{D}^{\prime}\right|\right)$ and $\mathrm{r}^{2}$ values. All four SNPs have strong LDs with $\mathrm{D}^{\prime}$ values of 1.0 according to the $\left(\left|\mathrm{D}^{\prime}\right|\right)$ value. In addition, the $\mathrm{r}^{2}$ value showed a value of 1.0 between c.149G $>A$ and c.556G $>C$ and between c.447T $>C$ and c.465C $>$ T (Table 2). Next, we performed haplotype analysis of the dog PRND gene. The two major haplotypes were identified, including GGTC and ACTC, and the GGTC haplotype had the highest frequency $(87.4 \%)$ in the dog PRND gene (Table 3).

Table 2. Linkage Disequilibrium (LD) among four polymorphisms of PRND gene in dogs.

\begin{tabular}{ccccc}
\hline \multicolumn{5}{c}{$\left|\mathbf{D}^{\prime}\right|$} \\
\hline $\mathrm{r}^{2}$ & $\mathrm{c} .149 \mathrm{G}>\mathrm{A}$ & $\mathrm{c} .447 \mathrm{~T}>\mathrm{C}$ & $\mathrm{c} .465 \mathrm{C}>\mathrm{T}$ & $\mathrm{c} .556 \mathrm{G}>\mathrm{C}$ \\
\hline $\mathrm{c} .149 \mathrm{G}>\mathrm{A}$ & - & 1.0 & 1.0 & 1.0 \\
c.447T $>\mathrm{C}$ & 0 & - & 1.0 & 1.0 \\
c.465C $>\mathrm{T}$ & 0 & 1.0 & - & 1.0 \\
c.556G $>\mathrm{C}$ & 1.0 & 0 & 0 & - \\
\hline
\end{tabular}

Table 3. Haplotype frequency of four PRND polymorphisms in dogs.

\begin{tabular}{cc}
\hline Haplotype & Dogs $(\boldsymbol{n}=\mathbf{4 1 4})$ \\
\hline GGTC & $362(0.874)$ \\
ACTC & $51(0.123)$ \\
Others & $1(0.003)$ \\
\hline
\end{tabular}


Next, we compared the genotype and allele frequencies of the c.149G $>$ A (R50H) SNP in the dog $P R N D$ gene among eight dog breeds using the chi-square test. Maltese has no significant difference from Pomeranian $(p=0.454)$, Chihuahua $(p=1.0)$, Mixed $(p=0.155)$, and Cocker Spaniel $(p=0.488)$ in genotype frequency. However, Maltese has a significantly different genotype distribution with Shih Tzu $(p=0.0019)$, Toy Poodle $(p=0.0036)$ and Yorkshire Terrier $(p=0.0067)$. In addition, the allele frequency of Maltese was significantly different from that of Shih Tzu $(p=0.0014)$, Toy Poodle $(p=0.0058)$ and Yorkshire Terriers $(p=0.005)$ (Figure 2).
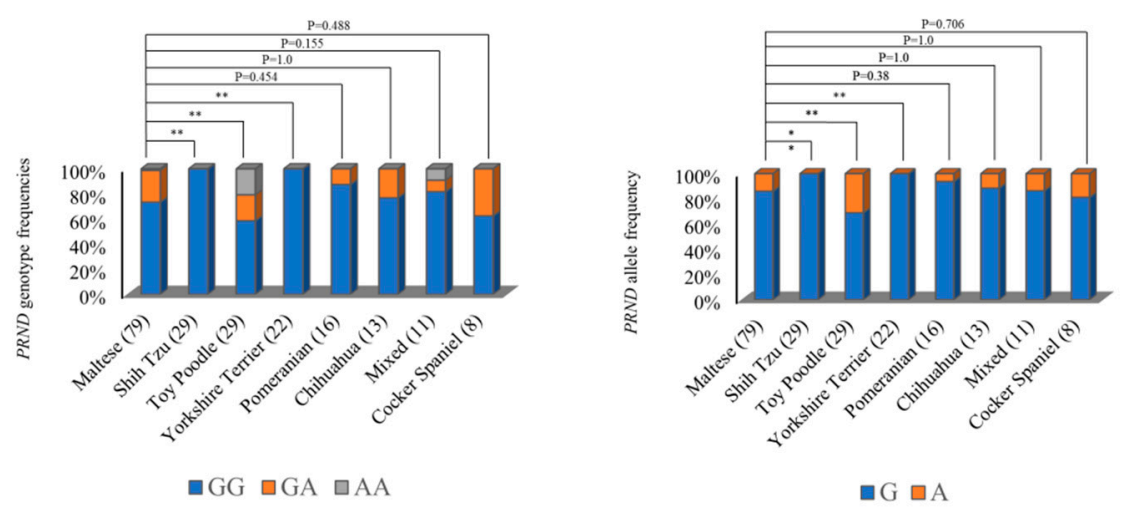

Figure 2. Comparisons of genotype and allele frequencies of c.149G $>$ A (R50H) among eight dog breeds. Differences in the c.149G>A (R50H) genotype and allele frequencies among eight dog breeds (Maltese, Shih Tzu, Toy Poodle, Yorkshire Terrier, Pomeranian, Chihuahua, Cocker Spaniel, and Mixed dogs) were calculated by the chi-square test using Statistical Analysis Software (SAS) version 9.4. Parentheses indicate the number of dogs. Statistically significant differences are indicated below. ${ }^{*} p$ value $<0.05$, ** $p$ value $<0.01,{ }^{* * *} p$ value $<0.001$

\subsection{Analysis of the Genetic Linkage between SNPs of the PRNP and PRND Genes}

To examine whether dog PRND SNPs have a genetic linkage with SNPs of the dog PRNP gene, we carried out LD analysis between SNPs of these two genes. Figure 3 summarizes LD analysis using the $\mathrm{r}^{2}$ value. Interestingly, all PRND SNPs showed weak LD with PRNP SNPs ( $\mathrm{r}^{2}$ value: below 0.3$)$. Detailed values are described in Supplementary Tables S1 and S2.

\section{LD score of PRNP and PRND SNPs}

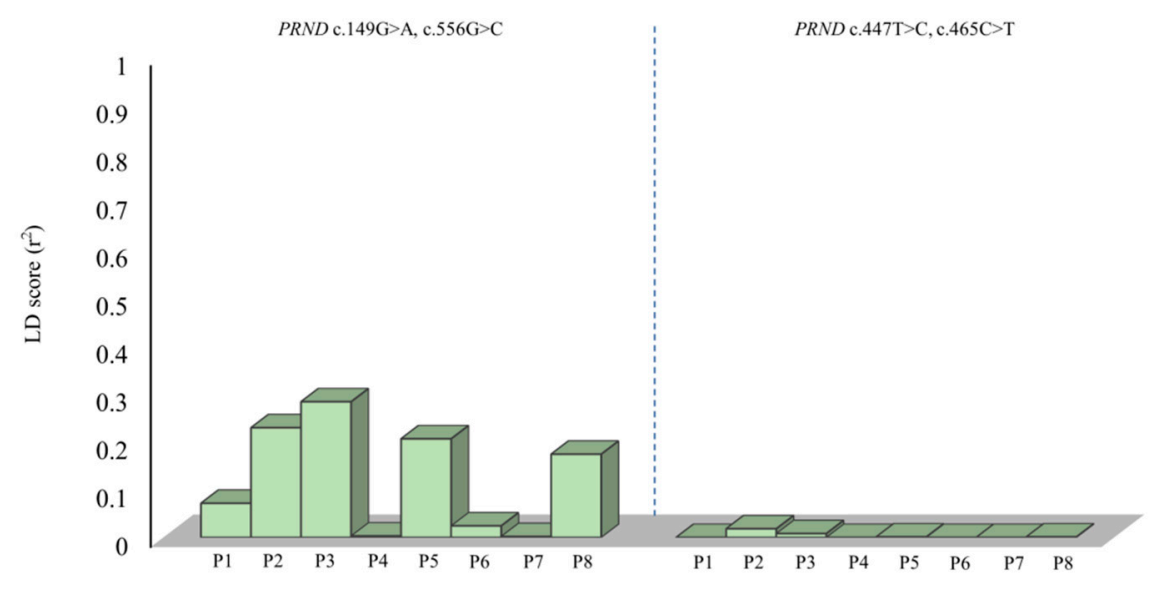

Figure 3. The linkage disequilibrium (LD) scores between polymorphisms of the PRND gene and those of the PRNP gene. LD scores with $\mathrm{r}^{2}$ values between PRND and PRNP polymorphisms in dogs. P1-P8 indicate PRNP polymorphisms as follows: P1, c.190in/del (codon 64); P2, c.198T>C (codon 66); P3, c.301A >G (codon 101); P4, c.372G $>$ A (codon 124); P5, c.489C >G (codon 163); P6, c.545A >G (codon 182); P7, c.546C >A (codon 182); and P8, c.729T>C (codon 243). 


\subsection{Measurement of Protein Functional Alterations Induced by Nonsynonymous SNPs}

We measured the damage of nonsynonymous SNPs (R50H) using PolyPhen-2, PROVEAN and PANTHER. PolyPhen-2 predicted R50H to be 'benign' and scored 0.051. The PROVEAN program analyzed $\mathrm{R} 50 \mathrm{H}$ to be 'neutral', with a score of -1.065 . PANTHER predicted $\mathrm{R} 50 \mathrm{H}$ to be 'probably benign' and scored 30 (Table 4).

Table 4. Prediction of non-synonymous polymorphisms in dogs by PolyPhen-2, PROVEAN and PANTHER.

\begin{tabular}{cccc}
\hline Variation & Method & Score & Prediction \\
\hline c.149G $>$ A & PolyPhen-2 & 0.051 & Benign \\
$(\mathrm{R} 50 \mathrm{H})$ & PROVEAN & -1.065 & Neutral \\
& PANTHER & 30 & Probably benign \\
\hline
\end{tabular}

\subsection{The Sequence Alignments of Doppel Protein among Several Species}

Finally, we performed amino acid sequence alignment of prion-like protein (Doppel) between dogs and other species (human, mouse, sheep, goat, rabbit, and horse). When compared to other species, dog prion-like protein has eight dog-specific amino acids, including leucine (L) in codon 18, glutamic acid (E) in codon 25, glycine (G) in codon 42 , serine (S) in codon 51, leucine (L) in codon 70, arginine (R) in codon 146, proline (P) in codon 157, and alanine (A) in codon 162 (Figure 4).

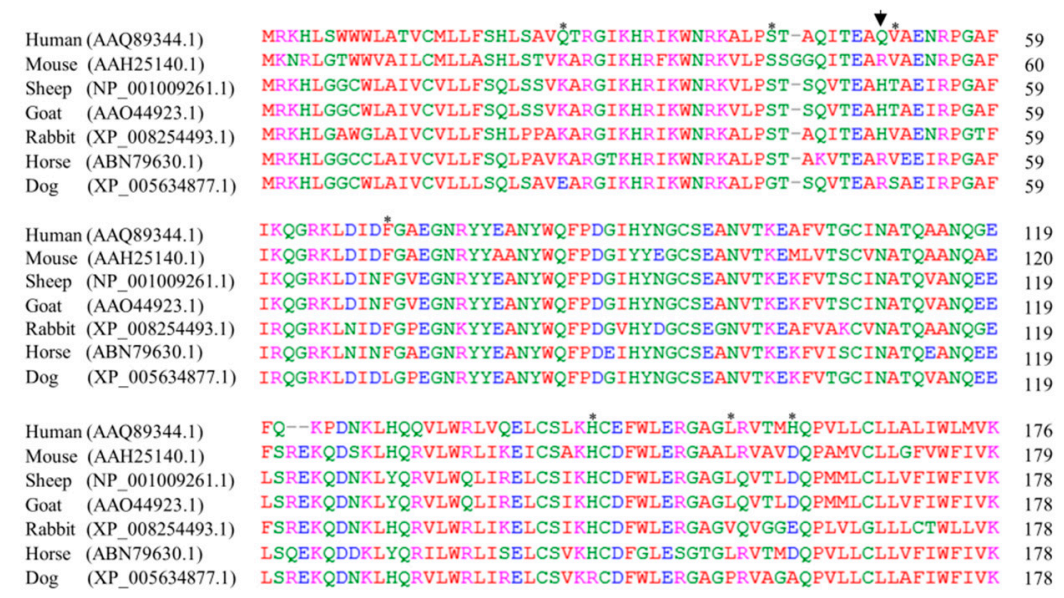

Figure 4. Comparisons of amino acid sequences of prion-like protein (Doppel) in human, mouse, sheep, goat, rabbit, horse, and dog. Prion-like protein sequences were obtained from GenBank at the National Center for Biotechnology Information (NCBI), including those of human (Homo sapiens, AAQ89344.1), mouse (Mus musculus, AAH25140.1), sheep (Ovis aries, NP_001009261.1), goat (Capra hircus, AAO44923.1), rabbit (Oryctolagus cuniculus, XP_008254493.1), horse (Equus caballus, ABN79630.1), and $\operatorname{dog}$ (Canis lupus familiaris, XP_005634877.1). Doppel protein sequences were aligned among various species using ClustalW2. Colors symbolize the chemical properties of amino acids (blue: acidic; red: small and hydrophobic; magenta: basic; green: hydroxyl, sulfhydryl, amine and glycine). The arrow denotes the nonsynonymous single nucleotide polymorphism (SNP) (c.149G>A, R50H) found in this study. Asterisks indicate dog-specific residues.

\section{Discussion}

The PRND gene is in the same family of genes as the PRNP gene. Structural similarities with the $P R N P$ gene and an association with prion disease have been reported in previous studies [44]. Recently, a strong genetic linkage between the PRNP gene and PRND gene was identified, and scrapie-associated SNPs were strictly linked to the genotype of the PRND gene $[38,41]$. Because those studies have been performed in prion disease-susceptible species, it is elusive whether strong genetic linkage was a prion disease-susceptible factor or a general property among prion gene families. Here, we first investigated 
dog PRND gene polymorphisms and analyzed the genetic linkage between the dog PRNP gene and the dog $P R N D$ gene. We found a total of four novel SNPs, including one nonsynonymous SNP. Among the four SNPs, the R50H SNP has already been identified in cattle. In addition, four PRND SNPs have a strong genetic linkage and construct two major haplotypes (Tables 2 and 3). Interestingly, genotype and allele frequencies are significantly different among eight dog breeds (Figure 2). Next, we investigated LD analysis between the PRNP gene and PRND gene. Notably, there was no strong LD between PRND and PRNP SNPs using $\mathrm{r}^{2}$ analysis. Previous studies have indicated that prion disease-susceptible species, such as sheep and goats, have a strong LD between the PRNP gene and the $P R N D$ gene, which is very interesting. Furthermore, because dogs have a relatively short genetic distance between the PRNP gene and PRND gene compared to those of other species (cattle: $26 \mathrm{~kb}$; goat: $21 \mathrm{~kb}$; sheep: $25 \mathrm{~kb}$; human: $20 \mathrm{~kb}$; horse: $16 \mathrm{~kb}$; dog: $17 \mathrm{~kb}$ ), weak LD between the PRNP and $P R N D$ genes was assumed not to be induced by the genetic distance between the PRNP gene and $P R N D$ gene. In addition, it is notable that prion disease-resistant animals, including horses and dogs, have a relatively short genetic distance between the PRNP gene and PRND gene compared to prion disease-susceptible animals. Because only three studies have performed (including the present study) LD analysis between the PRNP and PRND gene, further investigation of LD in a wide range of animals in the future is highly desirable. The important thing is that dogs did not have strong LD between the $P R N P$ gene and the PRND gene, unlike prion disease-susceptible species.

Finally, we estimated the nonsynonymous SNP R50H using PolyPhen-2, PROVEAN and PANTHER. Three in-silico estimation programs did not predict $\mathrm{R} 50 \mathrm{H}$ to be deleterious to doppel protein function. However, previous studies indicated that synonymous SNPs located in codon 26 of the PRND gene can impact Doppel function, especially the reproductive ability of sperm $[46,47]$. In addition, synonymous SNPs may impact transcription efficiency and can affect the phenotype of a protein [48]. Thus, in vivo or in vitro confirmation studies based on genotype, allele and haplotype distributions of the dog $P R N D$ gene will be needed in the future. In recent studies, the prion gene family member prion-related protein gene (PRNT), which is located downstream of the PRND gene, was expressed in reproductive organs in a manner similar to the PRND gene, and a strong genetic linkage with the PRND gene has also been reported [49-52]. Because a strong genetic LD block has been detected in sheep and goats, further confirmation of the genetic linkage between these adjacent genes is also needed in the future.

\section{Materials and Methods}

\subsection{Ethical Statement}

Whole blood samples of 207 dogs, including eight dog breeds (79 Maltese, 29 Shih Tzu, 29 Toy Poodle, 22 Yorkshire Terriers, 16 Pomeranian, 13 Chihuahua, 11 Mixed, 8 Cocker Spaniel), were provided by the Anyang cool pet animal hospital in the Republic of Korea. All experimental procedures were accredited by the Institute of Animal Care and Use Committee of Chonbuk National University (CBNU 2018-062) and approved on 27 July 2018.

\subsection{Genetic Analysis}

Genomic DNA was extracted from $200 \mu \mathrm{L}$ of a whole blood sample using a Hi Yield Genomic DNA Mini Kit (Real Biotech Corporation, Taipei, Taiwan) and a Bead Genomic DNA Prep Kit (Biofact, Daejeon, Korea). Polymerase chain reaction (PCR) was performed with forward primer: 5'-AGAAAGTAACTGCCCCGAGC-3' and reverse primer: $5^{\prime}$ TTTGGTACCTTGGGGACACG-3'. These primers were designed based on the PRND gene sequence from GenBank (Gene ID: 485782) and amplified DNA sequences containing the entire open reading frame (ORF) of the dog PRND gene. The length of the PCR products was $688 \mathrm{bp}$. A $25 \mu \mathrm{L}$ reaction mixture containing $2.5 \mu \mathrm{L}$ of 10X Taq DNA polymerase, $1 \mu \mathrm{L}$ of genomic DNA, 10 pmol each primer, $0.5 \mu \mathrm{L}$ of a $0.2 \mu \mathrm{M}$ dNTP mixture, $0.2 \mu \mathrm{L}$ of Taq DNA polymerase, and sterile deionized water, was used. The PCR conditions were as 
follows: denaturing at $95^{\circ} \mathrm{C}$ for $2 \mathrm{~min}$, followed by 34 cycles of $95^{\circ} \mathrm{C}$ for $20 \mathrm{~s}, 63^{\circ} \mathrm{C}$ for $30 \mathrm{~s}$, and $72{ }^{\circ} \mathrm{C}$ for $1 \mathrm{~min} 30 \mathrm{~s}$ and one cycle of $72{ }^{\circ} \mathrm{C}$ for $5 \mathrm{~min}$. The PCR products were separated on a $1 \%$ agarose gel stained with ethidium bromide (EtBr), and the PCR products were purified using a FavorPrep GEL/PCR Purification Mini Kit (FAVORGEN, Pingtung County, Taiwan). Purified PCR products were directly sequenced using an ABI 3730 sequencer (ABI, Foster City, CA, USA); sequencing results were visualized using Finch TV software (Geospiza Inc., Seattle, WA, USA), and genotyping was performed.

\subsection{Statistical Analysis}

Genotype and allele frequencies of the dog PRND gene were compared among eight dog breeds by chi-square test using SAS 9.4 software (SAS Institute Inc., Cary, NC, USA). Haplotype analysis and linkage disequilibrium calculated by Lewon-tin's $D^{\prime}\left(\left|D^{\prime}\right|\right)$ and pairwise linkage disequilibrium $\left(\mathrm{r}^{2}\right)$ were performed using Haploview version 4.2 (Broad Institute, Cambridge, MA, USA).

\subsection{Analysis of the Genetic Linkage between SNPs of the PRNP and PRND Genes}

LD analysis was performed between PRNP and PRND SNPs. LD scores of the PRNP and PRND genes were calculated in 174 animals. Next, the genotype distributions of $P R N D$ were compared with those of the PRNP gene, and the difference of distribution was calculated using the chi-square test. All statistical analyses were calculated by Statistical Analysis Software (SAS), version 9.4 (SAS Institute Inc., Cary, NC, USA), and statistically significant differences were determined by $p$ value $<0.05$.

\subsection{The Sequence Alignments of Doppel Protein among Several Species}

The alignments of the prion-like protein (Doppel) sequence were performed by ClustalW2 (http://www.ebi.ac.uk/Tools/msa/clustalo/). The analysis was performed for Doppel protein sequences of human (Homo sapiens, AAQ89344.1), mouse (Mus musculus, NC_000068.7), sheep (Ovis aries, NP_001009261.1), goat (Capra hircus, AAO44923.1), rabbit (Oryctolagus cuniculus, XP_008254493.1), horse (Equus caballus, ABN79630.1), and dog (Canis lupus familiaris, XP_005634877.1). All information of these sequences was obtained from GenBank at the National Center for Biotechnology Information (NCBI).

\subsection{Measurement of Protein Functional Alterations Induced by Nonsynonymous SNPS}

PolyPhen-2 (http:/ /genetics.bwh.harvard.edu/pph2/index.shtml), PROVEAN (http:/ / provean. jcvi.org/seq_submit.php), and PANTHER (http:/ / www.pantherdb.org/) programs have evaluated protein substitution by nonsynonymous SNPs. PolyPhen-2 evaluates the effect of amino acid changes according to the position-specific, independent count (PSIC) score and indicates three types of functional changes: "probably damaging", "possibly damaging" and "benign". PROVEAN estimates the impact score of nonsynonymous SNPs on protein function, with a score below -2.5 being "deleterious" and a score above -2.5 being "neutral". PANTHER uses a hidden Markov model (HMM)-based statistical modeling method to measure scores due to amino acid changes. The PANTHER score below -3 indicates "deleterious" and above -3 indicates "neutral".

\section{Conclusions}

In summary, we investigated SNPs of the dog PRND gene. We identified four novel SNPs, including 1 nonsynonymous SNP. A total of 4 SNPs constitute two major haplotypes with strong LD. In addition, we found significantly different distributions of genotype and allele frequencies among eight dog breeds. Furthermore, we evaluated the LD value between the PRNP gene and the PRND gene in dogs and found relatively weak LD compared to that in prion disease-susceptible animals, such as sheep and goats. Lastly, we performed in silico estimation of the nonsynonymous SNP of the PRND gene R50H using PolyPhen-2, PROVEAN and PANTHER. To the best of our knowledge, this is the first genetic study of the dog PRND gene. 
Supplementary Materials: Supplementary materials can be found at http:/ /www.mdpi.com/1422-0067/20/6/ 1404/s1. Table S1: Linkage Disequilibrium (LD) between polymorphisms (SNPs) of PRNP and PRND gene with $\mathrm{r}^{2}$ value in dogs. Table S2: Linkage Disequilibrium (LD) between polymorphisms of PRNP and PRND gene with $\mathrm{D}^{\prime}$ value in dogs.

Author Contributions: S.-Y.W., Y.-C.K. and B.-H.J. conceived and designed the experiment. S.-Y.W. and Y.-C.K. performed the experiments. Y.-C.K. and B.-H.J. analyzed the data. K.K. and A.-D.K. provided animal samples. K.K., A.-D.K., S.-Y.W., Y.-C.K. and B.-H.J. wrote the paper. All authors read and approved the final manuscript.

Funding: This research was supported by the Basic Science Program through the National Research Foundation of Korea (NRF) funded by the Ministry of Education, Science and Technology (2018R1D1A1B07048711). This research was supported by the Basic Science Research Program through the National Research Foundation of Korea (NRF) funded by the Ministry of Education (2017R1A6A1A03015876).

Acknowledgments: Sae-Young Won and Yong-Chan Kim were supported by the BK21 Plus Program in the Department of Bioactive Material Sciences.

Conflicts of Interest: The authors declare no conflict of interest.

$\begin{array}{ll}\text { Abbreviations } \\ \text { BSE } & \text { Bovine spongiform encephalopathy } \\ \text { CJD } & \text { Creutzfeldt-Jakob disease } \\ \text { CWD } & \text { Chronic wasting disease } \\ \text { FFI } & \text { Fatal familial insomnia } \\ \text { FSE } & \text { Feline spongiform encephalopathy } \\ \text { GSS } & \text { Gerstmann-Sträussler Scheinker syndrome } \\ \text { LD } & \text { Linkage disequilibrium } \\ \text { PRND } & \text { Prion-like protein gene } \\ \text { PRNP } & \text { Prion protein gene } \\ \text { SNPs } & \text { Single nucleotide polymorphisms (SNPs) } \\ \text { TME } & \text { Transmissible mink encephalopathy } \\ \text { TSEs } & \text { Transmissible spongiform encephalopathies }\end{array}$

\section{References}

1. Zabel, M.D.; Reid, C. A brief history of prions. Pathog. Dis. 2015, 73, ftv087. [CrossRef] [PubMed]

2. Prusiner, S.B. The prion diseases. Brain Pathol. 1998, 8, 499-513. [CrossRef] [PubMed]

3. Prusiner, S.B. Prions. Proc. Natl. Acad. Sci. USA 1998, 95, 13363-13383. [CrossRef]

4. Jewell, J.E.; Conner, M.M.; Wolfe, L.L.; Miller, M.W.; Williams, E.S. Low frequency of PrP genotype 225SF among free-ranging mule deer (Odocoileus hemionus) with chronic wasting disease. J. Gen. Virol. 2005, 86, 2127-2134. [CrossRef]

5. Brandt, A.L.; Kelly, A.C.; Green, M.L.; Shelton, P.; Novakofski, J.; Mateus-Pinilla, N.E. Prion protein gene sequence and chronic wasting disease susceptibility in white-tailed deer (Odocoileus virginianus). Prion 2015, 9, 449-462. [CrossRef]

6. Monello, R.J.; Galloway, N.L.; Powers, J.G.; Madsen-Bouterse, S.A.; Edwards, W.H.; Wood, M.E.; O'Rourke, K.I.; Wild, M.A. Pathogen-mediated selection in free-ranging elk populations infected by chronic wasting disease. Proc. Natl. Acad. Sci. USA 2017, 114, 12208-12212. [CrossRef]

7. Perucchini, M.; Griffin, K.; Miller, M.W.; Goldmann, W. PrP genotypes of free-ranging wapiti (Cervus elaphus nelsoni) with chronic wasting disease. J. Gen. Virol. 2008, 89, 1324-1328. [CrossRef]

8. Haase, B.; Doherr, M.G.; Seuberlich, T.; Drogemuller, C.; Dolf, G.; Nicken, P.; Schiebel, K.; Ziegler, U.; Groschup, M.H.; Zurbriggen, A.; et al. PRNP promoter polymorphisms are associated with BSE susceptibility in Swiss and German cattle. BMC Genet. 2007, 8, 15. [CrossRef]

9. Jeong, B.H.; Jin, H.T.; Carp, R.I.; Kim, Y.S. Bovine spongiform encephalopathy (BSE)-associated polymorphisms of the prion protein (PRNP) gene in Korean native cattle. Anim. Genet. 2013, 44, 356-357. [CrossRef]

10. Marsh, R.F.; Hadlow, W.J. Transmissible mink encephalopathy. Rev. Sci. Tech. 1992, 11, 539-550. [CrossRef]

11. Moennig, V. [Felinfo glossarium. Mad cow disease in the cat]. Tijdschr. Diergeneeskd. 1992, 117, 412-413. 
12. Baron, T.; Belli, P.; Madec, J.Y.; Moutou, F.; Vitaud, C.; Savey, M. Spongiform encephalopathy in an imported cheetah in France. Vet. Rec. 1997, 141, 270-271. [CrossRef]

13. Willoughby, K.; Kelly, D.F.; Lyon, D.G.; Wells, G.A. Spongiform encephalopathy in a captive puma (Felis concolor). Vet. Rec. 1992, 131, 431-434. [CrossRef]

14. Nurmi, M.H.; Bishop, M.; Strain, L.; Brett, F.; McGuigan, C.; Hutchison, M.; Farrell, M.; Tilvis, R.; Erkkila, S.; Simell, O; et al. The normal population distribution of PRNP codon 129 polymorphism. Acta. Neurol. Scand. 2003, 108, 374-378. [CrossRef]

15. Jeong, B.H.; Kim, Y.S. Genetic studies in human prion diseases. J. Korean. Med. Sci. 2014, $29,623-632$. [CrossRef]

16. Jeong, B.H.; Lee, Y.J.; Kim, N.H.; Carp, R.I.; Kim, Y.S. Genotype distribution of the prion protein gene (PRNP) promoter polymorphisms in Korean cattle. Genome 2006, 49, 1539-1544. [CrossRef]

17. Sander, P.; Hamann, H.; Drogemuller, C.; Kashkevich, K.; Schiebel, K.; Leeb, T. Bovine prion protein gene (PRNP) promoter polymorphisms modulate PRNP expression and may be responsible for differences in bovine spongiform encephalopathy susceptibility. J. Biol. Chem. 2005, 280, 37408-37414. [CrossRef]

18. Sailer, A.; Bueler, H.; Fischer, M.; Aguzzi, A.; Weissmann, C. No propagation of prions in mice devoid of PrP. Cell 1994, 77, 967-968. [CrossRef]

19. Fernandez-Borges, N.; Parra, B.; Vidal, E.; Erana, H.; Sanchez-Martin, M.A.; de Castro, J.; Elezgarai, S.R.; Pumarola, M.; Mayoral, T.; Castilla, J. Unraveling the key to the resistance of canids to prion diseases. PloS Pathog. 2017, 13, e1006716. [CrossRef]

20. Hunter, N.; Foster, J.D.; Goldmann, W.; Stear, M.J.; Hope, J.; Bostock, C. Natural scrapie in a closed flock of Cheviot sheep occurs only in specific PrP genotypes. Arch. Virol. 1996, 141, 809-824. [CrossRef]

21. Greenlee, J.J.; Kunkle, R.A.; Richt, J.A.; Nicholson, E.M.; Hamir, A.N. Lack of prion accumulation in lymphoid tissues of PRNP ARQ/ARR sheep intracranially inoculated with the agent of scrapie. PLoS ONE 2014, 9, e108029. [CrossRef]

22. Srithayakumar, V.; Mitchell, G.B.; White, B.N. Identification of amino acid variation in the prion protein associated with classical scrapie in Canadian dairy goats. BMC Vet. Res. 2016, 12, 59. [CrossRef]

23. Ortiz-Pelaez, A.; Georgiadou, S.; Simmons, M.M.; Windl, O.; Dawson, M.; Arnold, M.E.; Neocleous, P.; Papasavva-Stylianou, P. Allelic variants at codon 146 in the PRNP gene show significant differences in the risk for natural scrapie in Cypriot goats. Epidemiol. Infect. 2015, 143, 1304-1310. [CrossRef]

24. Colussi, S.; Vaccari, G.; Maurella, C.; Bona, C.; Lorenzetti, R.; Troiano, P.; Casalinuovo, F.; Di Sarno, A.; Maniaci, M.G.; Zuccon, F.; et al. Histidine at codon 154 of the prion protein gene is a risk factor for Nor98 scrapie in goats. J. Gen. Virol. 2008, 89, 3173-3176. [CrossRef]

25. Goldmann, W.; Martin, T.; Foster, J.; Hughes, S.; Smith, G.; Hughes, K.; Dawson, M.; Hunter, N. Novel polymorphisms in the caprine PrP gene: A codon 142 mutation associated with scrapie incubation period. J. Gen. Virol. 1996, 77, 2885-2891. [CrossRef]

26. Bouzalas, I.G.; Dovas, C.I.; Banos, G.; Papanastasopoulou, M.; Kritas, S.; Oevermann, A.; Papakostaki, D.; Evangelia, C.; Papadopoulos, O.; Seuberlich, T.; et al. Caprine PRNP polymorphisms at codons 171, 211, 222 and 240 in a Greek herd and their association with classical scrapie. J. Gen. Virol. 2010, 91, 1629-1634. [CrossRef]

27. Brandel, J.P.; Preece, M.; Brown, P.; Croes, E.; Laplanche, J.L.; Agid, Y.; Will, R.; Alperovitch, A. Distribution of codon 129 genotype in human growth hormone-treated CJD patients in France and the UK. Lancet. 2003, 362, 128-130. [CrossRef]

28. Jeong, B.H.; Lee, K.H.; Kim, N.H.; Jin, J.K.; Kim, J.I.; Carp, R.I.; Kim, Y.S. Association of sporadic Creutzfeldt-Jakob disease with homozygous genotypes at PRNP codons 129 and 219 in the Korean population. Neurogenetics 2005, 6, 229-232. [CrossRef]

29. Sanchez-Garcia, J.; Fernandez-Funez, P. D159 and S167 are protective residues in the prion protein from dog and horse, two prion-resistant animals. Neurobiol. Dis. 2018, 119, 11-12. [CrossRef]

30. Sanchez-Garcia, J.; Jensen, K.; Zhang, Y.; Rincon-Limas, D.E.; Fernandez-Funez, P. A single amino acid (Asp159) from the dog prion protein suppresses the toxicity of the mouse prion protein in Drosophila. Neurobiol. Dis. 2016, 95, 204-209. [CrossRef]

31. Polymenidou, M.; Trusheim, H.; Stallmach, L.; Moos, R.; Julius, C.; Miele, G.; Lenz-Bauer, C.; Aguzzi, A. Canine MDCK cell lines are refractory to infection with human and mouse prions. Vaccine 2008, 26, 2601-2614. [CrossRef] 
32. Kim, Y.C.; Jeong, M.J.; Jeong, B.H. The first report of genetic variations in the chicken prion protein gene. Prion. 2018, 12, 197-203. [CrossRef]

33. Kim, Y.C.; Jeong, B.H. The first report of polymorphisms and genetic characteristics of the prion protein gene (PRNP) in horses. Prion. 2018, 12, 245-252. [CrossRef]

34. Otero, A.; Bolea, R.; Hedman, C.; Fernández-Borges, N.; Marín, B.; López-Pérez, Ó.; Barrio, T.; Eraña, H.; Sánchez-Martín, M.A.; Monzón, M.; Badiola, J.J.; et al. An Amino Acid Substitution Found in Animals with Low Susceptibility to Prion Diseases Confers a Protective Dominant-Negative Effect in Prion-Infected Transgenic Mice. Mol. Neurobiol. 2018, 55, 6182-6192. [CrossRef]

35. Otero, A.; Hedman, C.; Fernández-Borges, N.; Eraña, H.; Marín, B.; Monzón, M.; Sánchez-Martín, M.A.; Nonno, R.; Badiola, J.J.; Bolea, R.; et al. A Single Amino Acid Substitution, Found in Mammals with Low Susceptibility to Prion Diseases, Delays Propagation of Two Prion Strains in Highly Susceptible Transgenic Mouse Models. Mol. Neurobiol. 2019. [CrossRef]

36. Jeong, B.H.; Kim, N.H.; Choi, E.K.; Lee, C.; Song, Y.H.; Kim, J.I.; Carp, R.I.; Kim, Y.S. Polymorphism at 3’ UTR +28 of the prion-like protein gene is associated with sporadic Creutzfeldt-Jakob disease. Eur. J. Hum. Genet. 2005, 13, 1094-1097. [CrossRef]

37. Peoc'h, K.; Guerin, C.; Brandel, J.P.; Launay, J.M.; Laplanche, J.L. First report of polymorphisms in the prion-like protein gene (PRND): Implications for human prion diseases. Neurosci. Lett. 2000, 286, 144-148. [CrossRef]

38. Mesquita, P.; Batista, M.; Marques, M.R.; Santos, I.C.; Pimenta, J.; Silva Pereira, M.; Carolino, I.; Santos Silva, F.; Oliveira Sousa, M.C.; Gama, L.T.; et al. Prion-like Doppel gene polymorphisms and scrapie susceptibility in Portuguese sheep breeds. Anim. Genet. 2010, 41, 311-314. [CrossRef]

39. Croes, E.A.; Alizadeh, B.Z.; Bertoli-Avella, A.M.; Rademaker, T.; Vergeer-Drop, J.; Dermaut, B.; Houwing-Duistermaat, J.J.; Wientjens, D.P.; Hofman, A.; Van Broeckhoven, C.; et al. Polymorphisms in the prion protein gene and in the doppel gene increase susceptibility for Creutzfeldt-Jakob disease. Eur. J. Hum. Genet. 2004, 12, 389-394. [CrossRef]

40. Kim, Y.C.; Jeong, B.H. Bovine spongiform encephalopathy (BSE) associated polymorphisms of the prion-like protein gene (PRND) in Korean dairy cattle and Hanwoo. J. Dairy Res. 2018, 85, 7-11. [CrossRef]

41. Jeong, M.J.; Kim, Y.C.; Jeong, B.H. Prion-like protein gene (PRND) polymorphisms associated with scrapie susceptibility in Korean native black goats. PLoS ONE 2018, 13, e0206209. [CrossRef]

42. Adzhubei, I.; Jordan, D.M.; Sunyaev, S.R. Predicting functional effect of human missense mutations using PolyPhen-2. Curr. Protoc. Hum. Genet. 2013. [CrossRef]

43. Choi, Y.; Chan, A.P. PROVEAN web server: A tool to predict the functional effect of amino acid substitutions and indels. Bioinformatics. 2015, 31, 2745-2747. [CrossRef]

44. Golaniska, E.; Flirski, M.; Liberski, P.P. Doppel: The prion's double. Folia neuropathologica 2004, 42, 47-54.

45. Thomas, P.D.; Campbell, M.J.; Kejariwal, A.; Mi, H.; Karlak, B.; Daverman, R.; Diemer, K.; Muruganujan, A.; Narechania, A. PANTHER: A library of protein families and subfamilies indexed by function. Genome Res. 2003, 13, 2129-2141. [CrossRef]

46. Paisley, D.; Banks, S.; Selfridge, J.; McLennan, N.F.; Ritchie, A.M.; McEwan, C.; Irvine, D.S.; Saunders, P.T.; Manson, J.C.; Melton, D.W. Male infertility and DNA damage in Doppel knockout and prion protein/Doppel double-knockout mice. Am. J. Pathol. 2004, 164, 2279-2288. [CrossRef]

47. Behrens, A.; Genoud, N.; Naumann, H.; Rulicke, T.; Janett, F.; Heppner, F.L.; Ledermann, B.; Aguzzi, A. Absence of the prion protein homologue Doppel causes male sterility. EMBO J. 2002, 21, 3652-3658. [CrossRef]

48. Komar, A.A. Silent SNPs: Impact on gene function and phenotype. Pharmacogenomics 2007, 8, 1075-1080. [CrossRef]

49. Pimenta, J.; Domingos, A.; Santos, P.; Marques, C.C.; Cantante, C.; Santos, A.; Barbas, J.P.; Baptista, M.C.; Horta, A.E.; Viegas, A.; et al. Is prnt a pseudogene? Identification of ram Prt in testis and ejaculated spermatozoa. PLoS ONE 2012, 7, e42957. [CrossRef]

50. Mesquita, P.; Garcia, V.; Marques, M.R.; Santos Silva, F.; Oliveira Sousa, M.C.; Carolino, I.; Pimenta, J.; Fontes, C.M.; Horta, A.E.; Prates, J.A.; et al. The prion-related protein (testis-specific) gene (PRNT) is highly polymorphic in Portuguese sheep. Anim. Genet. 2016, 47, 128-132. [CrossRef] 
51. Kim, Y.C.; Jeong, B.H. The first report of prion-related protein gene (PRNT) polymorphisms in goat. Acta. Vet. Hung. 2017, 65, 291-300. [CrossRef]

52. Kim, Y.C.; Jeong, B.H. First report of prion-related protein gene (PRNT) polymorphisms in cattle. Vet. Rec. 2018, 182, 717. [CrossRef] 